\title{
Pruning severity affects yield, fruit load and fruit and leaf traits of 'Brigitta' blueberry
}

\author{
E. Jorquera-Fontena ${ }^{1 *}$, M. Alberdi ${ }^{2}$ and N. Franck ${ }^{3}$ \\ ${ }^{1}$ Programa de Doctorado y Magister en Ciencias de Recursos Naturales, Universidad de La Frontera, \\ Temuco, Chile. \\ *Corresponding author emilio.jorquera@inia.cl \\ ${ }^{2}$ Departamento de Ciencias Químicas, Center of Plant-Soil Interaction and Natural Resources, Biotechnology, \\ Scientific and Technological Bioresource Nucleus (BIOREN), Universidad de La Frontera, Temuco, Chile. \\ ${ }^{3}$ Centro de Estudios de Zonas Áridas, Departamento de Producción Agrícola, Universidad de Chile, Santiago, \\ Chile.
}

\begin{abstract}
Pruning is crucial to balance productivity and fruit quality in blueberry orchards. Slight, conventional and severe pruning treatments were applied on 4- and 5-year old bluberry plants cultivar 'Brigitta' to evaluate their effect on yield, leaf area, gas exchange and fruit load as driver of fruit quality traits. Yield and berries per plant decreased with increasing pruning severity, whereas canopy leaf area increased. The resulting fruit load ranged from 0.2 to 1.4 fruit per $\mathrm{cm}^{2}$ leaf area. Fruit weight, dry matter, glucose and fructose were negatively related to fruit load, with fruit fresh weight decreasing to greater extent than sugars. Berry weight was restricted by source limitation during the initial cell division and initial cell enlargement fruit growth phases as indicated by decreased relative growth rate. Light-saturated photosynthetic rate diminished with increasing pruning severity indicating a sink limitation of photosynthesis. The strong association between photosynthesis and stomatal conductance shows a high corregulation in the response of carbon and water exchange to sink demand. Our results underline agronomic and physiological factors determining blueberry yield and fruit quality and can be useful for agro-technical management.
\end{abstract}

Keywords: Fruit weight, soluble sugars, canopy leaf area, photosynthesis 


\section{Introduction}

In southern Chile, blueberry orchards are oriented to the export market and are regularly cultivated under high input conditions. In these production systems, most blueberry cultivars tend to be very productive as a result of a high proportion of photo-assimilates allocated to fruit bud formation in the previous season. Although a high number of fruit buds per plant is desirable to achieve higher yield per unit area, the competition for assimilates among fruits can reduce whole-canopy leaf area, which leads to a lower fruit quality (Léchaudel et al., 2005). In fact, fruit weight and soluble sugar concentration typically decrease when the ratio between fruit number and leaf area (fruit load) is high. This is because the carbon source offer (mainly leaves) fails to meet the demand of carbon sinks (mainly fruits) (Seehuber et al., 2011; El-Boray et al., 2013). In order to balance fruit load, pruning is a crucial practice in blueberry production, with a positive effect on vegetative growth and fruit weight (Strick et al., 2003). However, if pruning is severely applied, a low fruit-to-leaf area ratio will develop, which can have a negative impact on gas exchange variables as occurs in several fruit species (Lechaudel et al., 2005; Franck et al., 2006; Quentin et al., 2013).

Although, the effect of pruning on blueberry fruit weight has been already reported (Strick et al., 2003), an approach based on fruit load has been not widely used to explain differences in fruit quality under field conditions. On the other hand, reports involving the physiological effects of pruning on leaf gas exchange variables are scarce in blueberry (Maust et al, 1999).
The aims of this study were 1) to examine the effect of different pruning severities on yield, whole-canopy leaf area and leaf gas exchange, and 2) to evaluate fruit load as a predictor of fresh weight, $\%$ dry matter and sugar concentration of blueberry fruit. Because periods in which increasing fruit load bring about reductions in the relative fruit growth rate (RGR) have been postulated as an indicator of a source limitation of fruit growth (Pavel and DeJong, 1993), the RGR was also estimated along the season. In order to reach the aims of this study, measurements were performed on field-grown highbush blueberry cv. 'Brigitta' (Vaccinium corymbosum L).

\section{Material and Methods}

\subsection{Plant material and treatments}

The experiments were carried out in a commercial blueberry orchard located in the Araucania Region, Chile (38 $29^{\prime} \mathrm{S} 72^{\circ} 23^{\prime} \mathrm{W}$ ). Plants were established at a spacing of $4 \times 0.9$ $\mathrm{m}$, in north-south oriented rows on an Andisol. Fertilizer was applied to achieve $70 \mathrm{~kg} \mathrm{~N} \mathrm{ha}{ }^{-1}$, $40 \mathrm{~kg} \mathrm{P}_{2} \mathrm{O}_{5} \mathrm{ha}^{-1}$ and $75 \mathrm{~kg} \mathrm{~K}_{2} \mathrm{O} \mathrm{ha}{ }^{-1}$. Irrigation was no limited in the orchard and pests and diseases were controlled according to the locally recommended practices.

In winter 2009 and 2010, three pruning severities were applied on 48 four- and five-year old blueberry plants cv. 'Brigitta' arranged in a randomized complete block design consisting of four replicated blocks distributed in two orchard rows. Treatments corresponded to: slight, conventional and severe pruning, which were applied according to the 
criteria described by Strik et al. (2003). All selected plants were first slightly pruned and then fruit buds were counted. Thereafter, conventional and severe prunings were applied and fruit buds per plant were adjusted targeting that conventionally and severely pruned plants had close to $50 \%$ and $20 \%$ of the fruit bud number present in slightly pruned plants (Table 1).

Table 1. Pruning treatments (slight, conventional and severe pruning) applied to 4-and 5- year old 'Brigitta' blueberry plants and fruit bud per plant resulting from pruning method. Percentage of fruit buds relative to slightly pruned plants are also shown.

\begin{tabular}{|l|l|l|l|}
\hline Pruning treatment & Plant age & Fruit buds plant & $\begin{array}{l}\text { Fruit buds relative to }^{-1} \\
\text { slight pruning } \\
\text { treatment (\%) }\end{array}$ \\
\hline Slight & 4-year old & $664.7 \pm 49.7$ & $\mathbf{1 0 0 . 0}$ \\
\hline & 5-year old & $799.7 \pm 12.0$ & $\mathbf{1 0 0 . 0}$ \\
\hline Conventional & 4-year old & $353.8 \pm 35.5$ & $\mathbf{5 3 . 2}$ \\
\hline & 5-year old & $416.8 \pm 38.5$ & $\mathbf{5 2 . 1}$ \\
\hline Severe & 4-year old & $146.7 \pm 14.4$ & $\mathbf{2 2 . 1}$ \\
\hline & 5-year old & $173.7 \pm 19.4$ & $\mathbf{2 1 . 7}$ \\
\hline
\end{tabular}

\subsection{Fruit measurements}

Fruits from each replicate were weighed every 5-8 days to estimate yield per plant. Mean berry weight was determined taking randomly 20 -fruit sample per plant at each harvest date. Samples were then dried at $65^{\circ} \mathrm{C}$ to a constant dry weight to determine $\%$ of dry matter in fruits. Fruit number per plant was estimated by division of yield by mean fruit weight.

Fruit soluble sugar concentration was determined on three 20 fruit-samples randomly collected in each treatment replicate when fruits had reached maturity, 100 days after bloom (DAB). Samples were frozen to $-80^{\circ} \mathrm{C}$ and then lyophilized. Sugars from ground freezedried fruits $(50 \mathrm{mg}$ ) were extracted in $80 \%$ ethanol, containing maltose $\left(3 \mathrm{gL}^{-1}\right)$ as internal standard, for $1 \mathrm{~h}$ at $60{ }^{\circ} \mathrm{C}$, and in distilled water under the same conditions. Each extraction was followed by centrifugation at 13,000 g. The pooled supernatants were used for sugar analysis. Soluble sugar extracts were analysed by high performance thin layer chromatography (CAMAG, Muttenz, Switzerland).

Fruit growth was assessed by measuring equatorial diameter with a digital calliper (accuracy $\pm 0.01 \mathrm{~mm}$ ). Measurements were periodically made on 4-year old plants from corolla fall until the moment when berries reached full blue colour. Six representative sun exposed clusters of fruits were selected from each treatment. In order to avoid the varability in fruit growth brought about by the high degree of asynchrony in fruit maturation within each bluebrrey cluster, only the five largest 
fruits within each cluster were used for growth determination, independently of their position within the inflorescence (modified from Godoy et al., 2008). For these data, an experimental non-linear regression $\left(\mathrm{R}^{2}=0.97, P<0.001, n=99\right)$ between fruit diameter $(d i)$ and fruit dry matter $\left(D M_{\mathrm{Fr}}\right)$ was applied in order to estimate seasonal increase of fruit dry matter:

$$
D M_{\mathrm{Fr}}=8 \times 10^{-5} \cdot d i^{2.81}
$$

The equation was constructed from fruits randomly taken from neighboring plants. From estimated fruit dry matter, the mean relative growth rate (RGR) was calculated as described by Reyes-Díaz et al., (2011):

$$
\mathrm{RGR}=\left(\ln D W_{\mathrm{Fr}} 2-\ln D W_{\mathrm{Fr}} 1\right) /\left(d_{1}-d_{2}\right)
$$

where $D W_{\mathrm{Fr}} 2$ and $D W_{\mathrm{Fr}} 1$ are the average fruit dry matter at subsequent dates $d_{2}$ and $d_{1}$, respectively.

\subsection{Whole-canopy leaf area and leaf gas exchange measurements}

Four representative plants per treatment were completely defoliated at the end of each harvest season to estimate the whole-canopy leaf area per plant $\left(\mathrm{m}^{2}\right)$. From defoliated plants, 100 $\mathrm{g}$ fresh leaves samples were taken and then scanned to estimate their leaf area using a program developed in our laboratory, which was previously validated (O'Neal et al., 2002). After scanning, samples were dried at $65^{\circ} \mathrm{C}$ to a constant dry weight along with the rest of collected leaves. The leaf area of samples was related with its dry matter in order to estimate whole-canopy leaf area from total leaf dry mass. Photosynthetic light-response curves were obtained on 4-year old plants at 67 and 94
DAB. At each date, six expanded leaves per treatment experiencing full sun exposure were measured between 8:30 and 14:00 hr. Leaves were selected from fruit-bearing shoots which were similar in vigour, length and number of fruit per leaf (1-1.4 fruits per leaf) to avoid the effect of nearby sinks (fruits) on the leaf photosynthesis and to test the hypothesis that light-saturated assimilation rates in these leaves is increased when a high fruit load results from slight pruning. An infrared gas analyzer (Li6400, LICOR, Nebraska, USA) connected to a broadleaf chamber and with automatic control of leaf temperature, photosynthetic photon flux density and $\mathrm{CO}_{2}$ concentration, was used for measurements. Leaf temperature was set at $20^{\circ} \mathrm{C}$ and ambient $\mathrm{CO}_{2}$ and $\mathrm{H}_{2} \mathrm{O}$ vapour concentrations were used during measurements. Light-response curves were constructed by plotting net photosynthetic against incident photosynthetci photon flux density (PPFD), which ranged from 0 to $1,500 \mu \mathrm{mol} \mathrm{m} \mathrm{m}^{-2} \mathrm{~s}^{-1}$. Stomatal conductance to water vapour $\left(g_{\mathrm{s}}\right.$, $\mu \mathrm{mol} \mathrm{H}_{2} \mathrm{O} \quad \mathrm{m}^{-2} \mathrm{~s}^{-1}$ ) and intercellular $\mathrm{CO}_{2}$ concentration $\left(C_{\mathrm{i}}, \mu \mathrm{mol} \mathrm{CO}_{2} \mu \mathrm{mol}^{-1}\right.$ photons $)$ were also recorded for each net photosynthesis value. Causton and Dale's (1990) model was fitted to light-response curves in order to estimate light-saturated photosynthetic rate $\left(A_{\mathrm{e}}^{\text {sat }}, \mu \mathrm{mol} \mathrm{CO}_{2} \mathrm{~m}^{-2} \mathrm{~s}^{-1}\right)$, dark respiration rate $\left(R_{\mathrm{d}}, \mu \mathrm{mol} \mathrm{CO}_{2} \mathrm{~m}^{-2} \mathrm{~s}^{-1}\right)$ and maximal quantum use efficiency of $\mathrm{CO}_{2}$ assimilation as the initial slope of the photosynthetic light-response curve $\left(-a_{\text {light }}, \mu \mathrm{mol} \mathrm{CO} \mathrm{Cmol}^{-1}\right.$ photons $)$ :

$A_{n}=A_{e}^{\text {sat }}\left[1-e^{(\text {-a light PPFD })}\right]-\mathrm{R}_{\mathrm{d}}$ 
where $A_{\mathrm{n}}$ is net photosynthesis ( $\mu \mathrm{mol} \mathrm{CO}_{2} \mathrm{~m}^{-2}$ $\mathrm{s}^{-1}$ ) and PPFD is photosynthetic photon flux density $\left(\mu \mathrm{mol} \mathrm{m} \mathrm{m}^{-2} \mathrm{~s}^{-1}\right)$.

\subsection{Statistical analysis}

One and two-way ANOVAs were performed to identify the effect of treatment and the interactive effect between treatment and plant age on the studied varibles. Fruit weight, dry matter and soluble sugar concentration were analyzed through regressions with fruit load as explanatory variable. To evaluate association among measured gas exchage variables, regression analysis was also performed. A Tukey test $(\mathrm{P}<0.05)$ was used to separate means. All data analyses and methods used for fitting models were carried out with $\mathrm{R}$ software through $\mathrm{R}$ Commander (Rcmdr version 1.8-3 in $\mathrm{R}$ version 2.14.2), and ' $\mathrm{nls}$ ' function ( $\mathrm{R}$ version 2.15.0), respectively.

\section{Results}

3.1. Yield, berries per plant, fruit weight, leaf area and resulting fruit load

Yield and berries per plant significantly increased with decreasing pruning severity (Table 2). For 4-year old plants, the slightly pruned plants had 1.3 times and 2.2 times higher yields than conventionally and severely pruned plants, respectively. For 5-year old plants, these differences slightly increased reaching 1.7 times and 2.6 times, respectively. The differences in berry number per plant were higher than those in yield due to the compensatory effect of pruning severity on fruit weight (Table 2). Thus, for 4-year old and 5-year old plants, berries per plant increased 3.5 times and 4.3 times, from severely to slightly pruned plants, respectively. A significant interaction between pruning severity and plant age was observed for berries per plant (Table 2).

Table 2. Effect of pruning severity treatments (slight, conventional and severe pruning) on yield, berry weight, berries per plant, leaf area and resulting fruit load of 4- and 5-year old blueberry plants cv. 'Brigitta' in the field. Mean values of the treatments and standard errors are shown.

\begin{tabular}{|c|c|c|c|c|c|c|}
\hline $\begin{array}{l}\text { Pruning } \\
\text { treatment } \\
\text { (T) }\end{array}$ & $\begin{array}{l}\text { Plant age } \\
\text { (PA) }\end{array}$ & $\begin{array}{l}\text { Yield (kg } \\
\left.\text { plant }^{-1}\right)\end{array}$ & $\begin{array}{l}\text { Fruit } \\
\text { weight (g) }\end{array}$ & $\begin{array}{l}\text { No Fruit } \\
\text { plant }^{-1}\end{array}$ & $\begin{array}{l}\text { Leaf area } \\
\left(\mathrm{m}^{2} \text { plant }^{-1}\right)\end{array}$ & $\begin{array}{l}\text { Fruit load } \\
\text { (fruit } \mathrm{cm}^{-2} \text { leaf } \\
\text { area) }\end{array}$ \\
\hline \multirow{2}{*}{ Slight } & 4-year old & $3.72 \pm 0.14$ bd & $1.22 \pm 0.04 \mathrm{c}$ & $3077.7 \pm 204.4 \mathrm{c}$ & $2.62 \pm 0.04 \mathrm{c}$ & $1.19 \pm 0.26 \mathrm{~b}$ \\
\hline & 5 -yerd old & $4.72 \pm 0.18 \mathrm{~d}$ & $1.15 \pm 0.09 \mathrm{c}$ & $4145.8 \pm 226.2 \mathrm{c}$ & $3.04 \pm 0.19 \mathrm{bc}$ & $1.41 \pm 0.27 \mathrm{~b}$ \\
\hline \multirow{2}{*}{ Conventional } & 4-year old & $2.82 \pm 0.32 \mathrm{bc}$ & $1.56 \pm 0.04 \mathrm{~b}$ & $1801.2 \pm 191.2 \mathrm{~b}$ & $3.45 \pm 0.06 \mathrm{bc}$ & $0.53 \pm 0.31 \mathrm{a}$ \\
\hline & 5 -yerd old & $3.03 \pm 0.16 \mathrm{bc}$ & $1.53 \pm 0.07 \mathrm{~b}$ & $1984.5 \pm 107.5 \mathrm{~b}$ & $4.03 \pm 0.04 \mathrm{ab}$ & $0.50 \pm 0.35 \mathrm{a}$ \\
\hline \multirow{2}{*}{ Severe } & 4-year old & $1.68 \pm 0.18 \mathrm{a}$ & $1.98 \pm 0.05 \mathrm{a}$ & $858.5 \pm 110.4 \mathrm{a}$ & $4.13 \pm 0.04 \mathrm{ab}$ & $0.21 \pm 0.24 \mathrm{a}$ \\
\hline & 5 -yerd old & $1.94 \pm 0.39 \mathrm{ac}$ & $1.99 \pm 0.07 \mathrm{a}$ & $967.0 \pm 175.9 \mathrm{a}$ & $4.95 \pm 0.05 \mathrm{a}$ & $0.21 \pm 0.35 \mathrm{a}$ \\
\hline Effect of $T$ & & $<0.001$ & $<0.001$ & $<0.001$ & $<0.001$ & $<0.001$ \\
\hline Effect of PA & & 0.31 & 0.57 & 0.38 & 0.118 & 0.77 \\
\hline T X PA & & 0.23 & 0.85 & 0.025 & 0.79 & 0.31 \\
\hline
\end{tabular}


Mean berry weight significantly varied with pruning method with slightly pruned plants having $40 \%$ smaller berries than severely pruned plants. No significant effect of plant age and pruning treatment $\mathrm{x}$ plant age interaction on berry weight was observed (Table 2). Total yield was negatively correlated with berry weight $\left(\mathrm{R}^{2}=0.66, \mathrm{P}<0.001\right)$. Pruning severity significantly affected canopy leaf area, while plant age and the interaction between pruning treatments and plant age did not (Table 2). Thus, canopy leaf area increased by close to $60 \%$ from slightly to severely pruned plants, considering the mean value of both plant ages (Table 2). Treatments were effective in generating significant differences in fruit load with values ranging from 0.21 to 1.41 fruits $\mathrm{cm}^{-2}$ leaf area. Plant age and pruning treatment $\mathrm{x}$ plant age interaction did not alter fruit load.

\subsection{Fruit load as a predictor of fruit quality}

Berry weight and dry matter (\%DM) were significantly and negatively correlated to fruit load, with fruit load accounting for over $70 \%$ of the variance for both variables (Figure 1A and $\mathrm{B})$. As observed in figure $1 \mathrm{~A}$, the $\% \mathrm{DM}$ decreased in lower extent than berry weight as fruit load increased. Thus berry weight decreased by $50 \%$, whereas $\%$ DM by only $6 \%$ when comparing severely and slightly pruned plants.

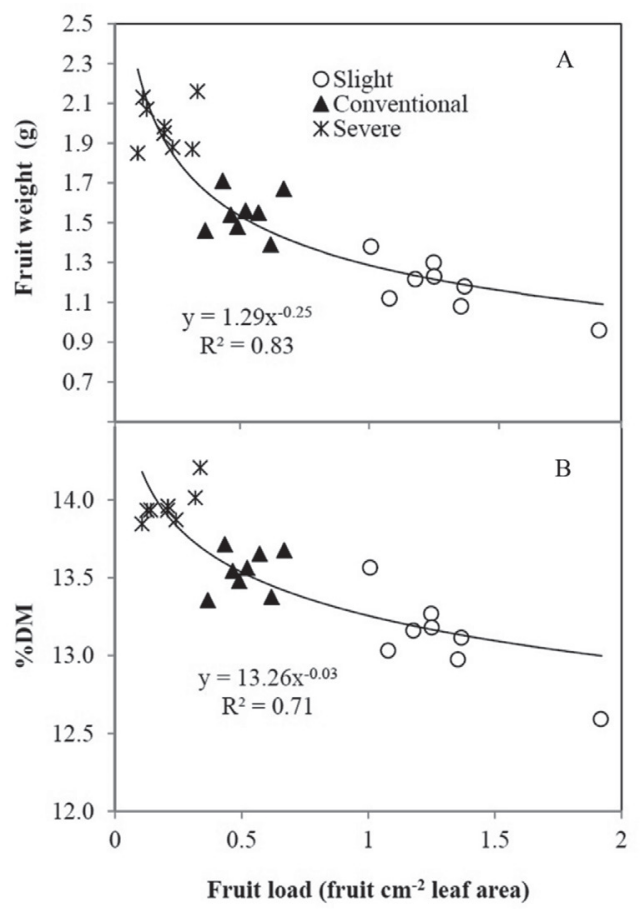

Figure 1. Fruit fresh weight (A) and fruit dry matter (\%) (B) as a function of fruit load for 'Brigitta' highbush blueberry plants subjected to slight, conventional and severe pruning. Mean values of replicates $(n=4)$, non-linear regression and $\mathrm{R}^{2}$ value are shown. 
Sugars other than glucose and fructose were not detected in this study. Decreasing fruit load led to increased fructose, glucose and, thus, total sugar concentrations in fruits (Figure 2A, $B$ and $C$ ). Soluble sugars were significantly related to fruit load through a potential fit with fruit load accounting for over 53\% of the variance in sugar concentration. Total fruit sugar concentration increased close to $9 \%$ from slightly to severely pruned plants. Differences in fructose and glucose were similar to those observed for total sugar concentration. Glucose contributed more than fructose to the total soluble sugars; but differences between both sugars were not greater than $6 \%$. The $\% \mathrm{DM}$ in fruits was positively and significantly correlated to the increment in total soluble sugars $\left(\mathrm{R}^{2}=\right.$ $0.43, P<0.01)$.

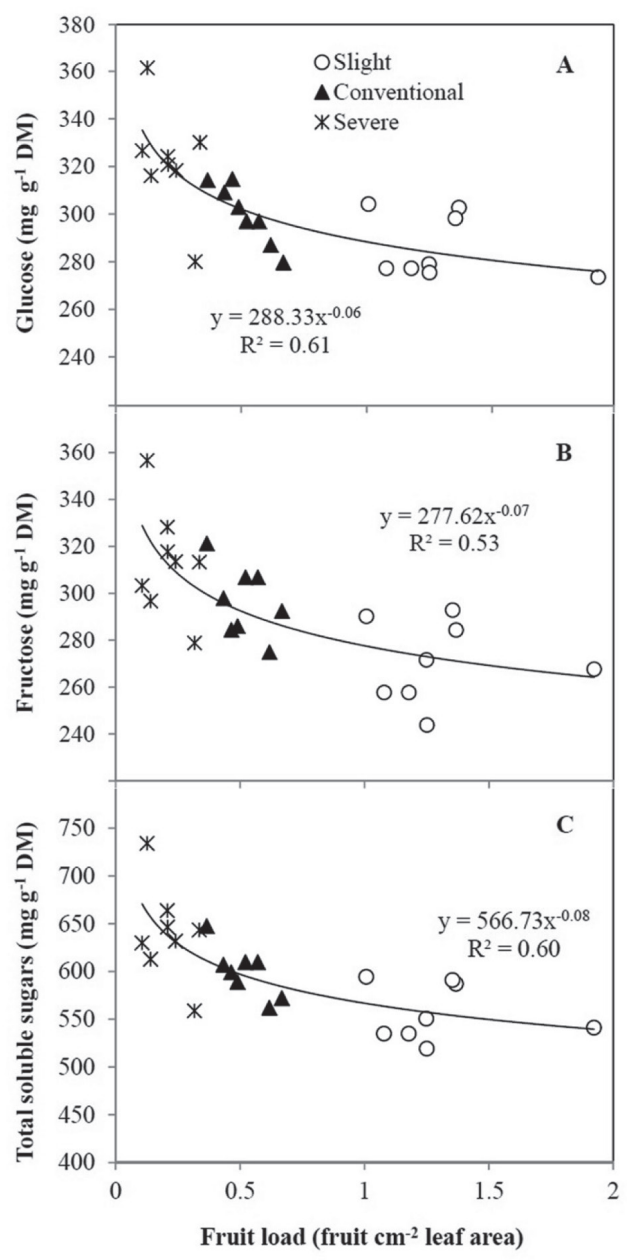

Figure 2. Glucose (A), fructose (B) and total soluble sugars (C) as a function of fruit load for 'Brigitta' highbush blueberry plants subjected to slight, conventional and severe pruning. Mean values of replicates $(n=4)$, non-linear regression and $\mathrm{R}^{2}$ value are shown. 


\subsection{Fruit growth}

Measurements of fruit diameter reproduced the double-sigmoid pattern of blueberry fruit growth and accounted for the effect of pruning severity on fruit weight gain, herby validating the use of fruit diameter for estimating RGR (Figure $3 \mathrm{~A}$ and B).

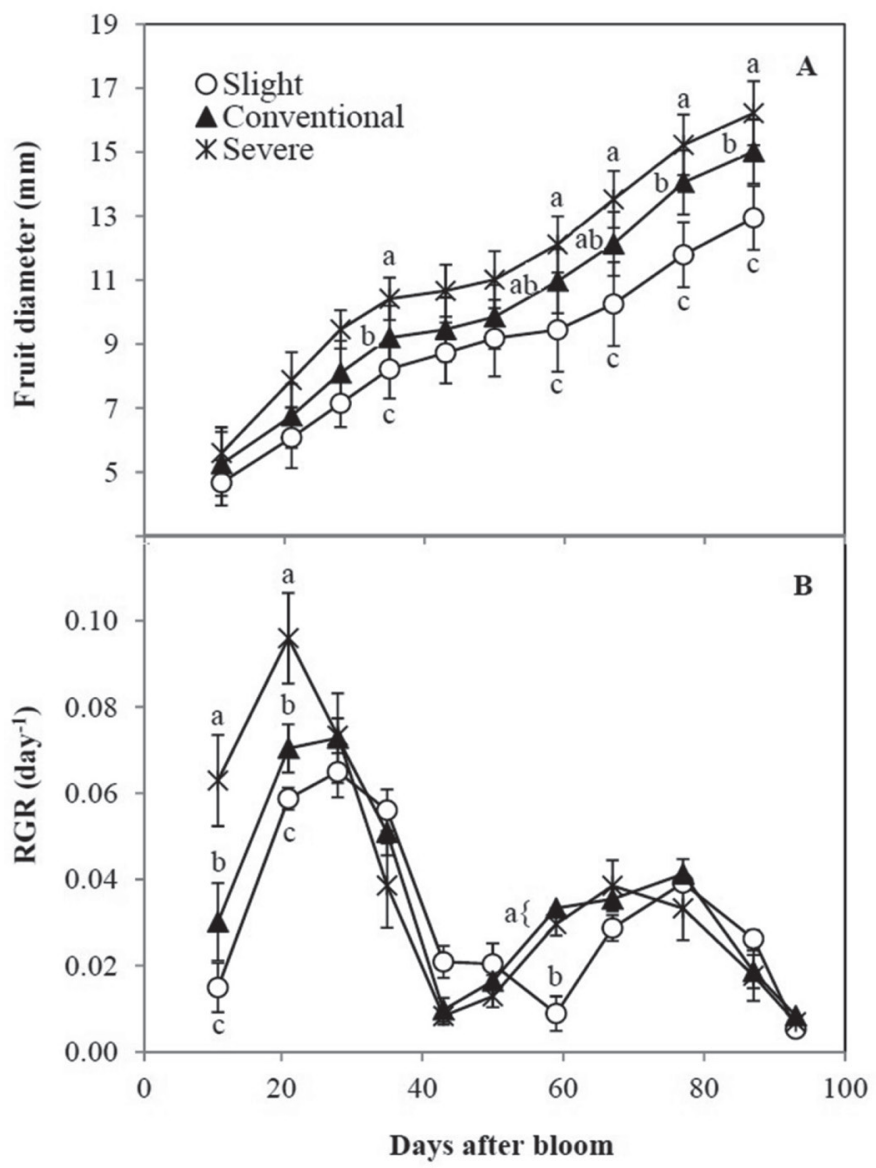

Figure 3. Seasonal course of mean fruit diameter (A) and relative fruit growth rate (B) for four-year old 'Brigitta' blueberry plants subjected to slight, conventional and severe pruning. Means $(n=30)$ and standard errors (bars) are shown. Letters indicate significant differences (Tukey test at $a=0.05$ ), for each date in which the effect of treatment was significant. 
As observed in the figure, pruning severity significantly affected RGR at 11,21 and 59 DAB, with fruits from severely and conventionally pruned plants having higher RGR values than fruits from slightly pruned plants for these dates.

\subsection{Leaf gas exchange}

The photosynthetic light-response curves per pruning treatment were unaffected by the date in which they were performed (67 and $94 \mathrm{DAB}$, data not shown). The $A_{\mathrm{n}}$ reached light saturation at $700 \mu \mathrm{mol} \mathrm{m}^{-2} \mathrm{~s}^{-1}$ PPFD (Figure 4).

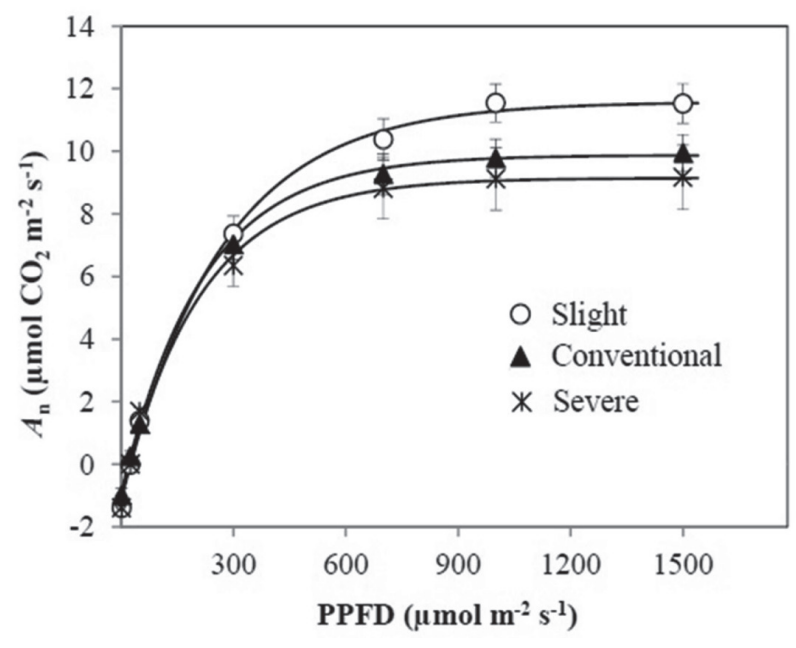

Figure 4. Leaf net photosynthesis $\left(A_{\mathrm{n}}\right)$ as a function of photosynthetic photon flux density (PPFD) for four-year old highbush blueberry plants cv. 'Brigitta' subjected to slight, conventional and severe pruning. Means for two dates of each treatment $(n=12)$ and standard deviation (bars) are shown.

The asymptotic model (3) was significantly fitted for each photosynthetic light-response curve constructed $\left(\mathrm{R}^{2}>0.90, \quad \mathrm{P}<0.001\right.$ for all empirical coefficients). The $A_{\mathrm{e}}^{\text {sat }}$ was significanly affected by pruning treatments, with leaves in the slightly pruned plants having $15 \%$ and $24 \%$ higher rates than leaves in the conventionally and severely pruned plants, respectively (Table 3 ). The $R_{\mathrm{d}}$ and $a_{\text {light }}$ were unaffected by pruning severity (Table 3 ). 
Table 3. Effect of pruning severity treatments (slight, conventional and severe pruning) on estimated light-saturated photosynthesis $\left(A_{e}^{\text {sat }}\right)$, dark respiration $\left(R_{\mathrm{d}}\right)$, and quantum use efficiency for $\mathrm{CO}_{2}$ assimilation $\left(a_{\text {light }}\right)$ of four-year old 'Brigitta' highbush blueberry plants. Mean of two dates for each treatment $(n=12)$, standard error and letters indicating statistical differences $(a=0.05)$ are shown.

\begin{tabular}{llll}
\hline $\begin{array}{l}\text { Pruning } \\
\text { treatment }\end{array}$ & $\begin{array}{l}\boldsymbol{A}_{\mathrm{e}}^{\text {sat }} \\
\left(\boldsymbol{\mu m o l ~} \mathbf{C O}_{2} \mathbf{~ m}^{-2} \mathbf{s}^{-\mathbf{1}}\right)\end{array}$ & $\begin{array}{l}\boldsymbol{R}_{\mathrm{d}} \\
\left(\mu \mathbf{m o l ~} \mathbf{C O}_{2} \mathbf{~ m}^{-2} \mathbf{s}^{-1}\right)\end{array}$ & $\begin{array}{l}\boldsymbol{a}_{\text {light }} \\
\left(\mu \mathbf{m o l ~ C O} \mathbf{C O}_{2} \mathbf{m o l}^{-1} \text { photons }\right)\end{array}$ \\
\cline { 2 - 4 } Slight & $12.70( \pm 0.36) \mathrm{a}$ & $0.92( \pm 0.26) \mathrm{a}$ & $0.003( \pm 0.0004) \mathrm{a}$ \\
Conventional & $11.05( \pm 0.49) \mathrm{b}$ & $0.99( \pm 0.40) \mathrm{a}$ & $0.004( \pm 0.0007) \mathrm{a}$ \\
Severe & $10.24( \pm 0.62) \mathrm{b}$ & $1.09( \pm 0.51) \mathrm{a}$ & $0.004( \pm 0.001) \mathrm{a}$
\end{tabular}

At saturating light $\left(1,500 \mu \mathrm{mol} \mathrm{m} \mathrm{m}^{-2} \mathrm{~s}^{-1}\right)$, the observed net photosynthesis $\left(A^{\text {sat }}\right)$ and stomatal conductance $\left(g_{s}\right)$ were correlated through a potential fit with $g_{\mathrm{s}}$ accounting for $68 \%$ of the variance of $A^{\text {sat }}$ (Figure 5A). The same trend was observed when $C_{\mathrm{i}}$ was plotted against $g_{\mathrm{s}}$. For this fit, $g_{\mathrm{s}}$ accounted for $67 \%$ of the variance of $C_{\mathrm{i}}$ (Figure 5B).

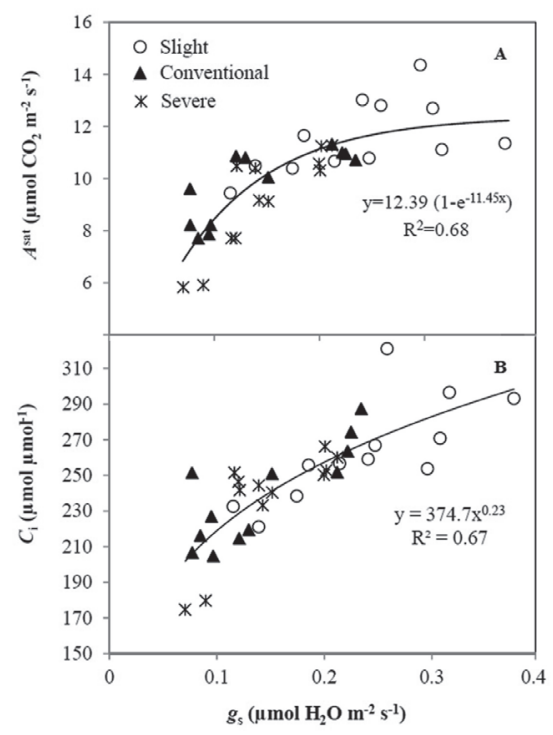

Figure 5. Light-saturated photosynthesis rate $\left(A_{\text {sat }}\right)(\mathrm{A})$ and gs plotted against internal $\mathrm{CO} 2$ concentration $\left(C_{\mathrm{i}}\right)(\mathrm{B})$ as a function of stomatal conductance to water vapour $\left(g_{\mathrm{s}}\right)$ for highbush blueberry plants cv. 'Brigitta' subjected to slight, conventional and severe pruning. Mean values $(n=36)$ measured at saturating PPFD, non-linear regressions and $\mathrm{R}^{2}$ values are presented. 


\section{Discussion}

Pruning is a crucial cultural practice in blueberry production, which provides physical structure to support the current fruit load and sustainability for fruit production in the long-term. Lesser removed wood in 'Brigitta' blueberry plants stimulated a greater yield and berries per plant but reduced whole-canopy leaf area (Table 2). The increase in yield and berries per plant was not proportional to the decrease in canopy leaf area when comparing severely and slightly pruned plants. While yield and berries per plant increased close to 2.3 and 4.0 times, respectively, as mean value of both plant ages, the canopy leaf area decreased by around $40 \%$. This suggests that fruits have higher ability to attract assimilates than leaves and that fruits compete more between them than with shoots, as observed in several species (Gautier et al., 2001; Minchin et al., 2010; El-Boray et al., 2013). Our study showed that 'Brigitta' blueberry fruit weight, \%DM and sugars decreased curvilinearly with increasing fruit load (Figure 1 and 2). This confirms that pruning severity has an impact on important blueberry fruit quality attributes (Retamales and Hancock, 2012) by regulating the ratio between fruit and canopy leaf area. Although an increasing pruning severity enhanced fruit weight, it did not compensate for the loss in yield per plant. This indicates that yield was limited by sink potential when 'Brigitta' blueberry plants were subjected to severe pruning.

According to Pavel and DeJong (1993), the periods in which fruit growth is limited by carbon supply can be detected by estimating the relative fruit growth rate (RGR). Thus, when fruit growth is not source-limited, no differences in RGR between fruit growing under different pruning severities should appear. Based on blueberry fruit development phases, in which cell division, the development of the embryo and endosperm tissues and cell enlargement occur in parallel with the changes in accumulated fruit size (Godoy et al., 2008) (Figure 3A), the significant effect of pruning treatments on RGR values at 11, 21 and 59 DAB (Figure 3B) suggests that, in the conventional and slight pruning treatments, the cell division phase experienced a source-limitation, which also occured in the cell enlargment phase for the slight pruning treatment. According to Henton et al. (1999), a source-limited period during early fruit growth may be more detrimental to final weight than equivalent limitations during more advanced stages.

In order to meet the high carbon demand excerted by growing fruits and to counterbalance a reduced increment in canopy leaf area, an enhanced photosynthetic rate was observed in leaves of slightly pruned plants (Figure 4, Table $3)$. This indicates that photosynthetic potential of sun exposed leaves from conventionally and severely pruned plants was operating below its maximum potential. The negative impact of low fruit load on leaf photosynthesis is consistent with observation on several fruit crops including fruit-bearing blueberry shoots (Maust et al., 1999). Because our photosynthetic lightresponse curves were assessed on leaves selected from fruiting shoots similar in vigour and fruit load, irrespective of treatment, we can suggest that a high light-saturated photosynthesis was driven by an enhanced assimilate export from these shoots for supplying carbon to the rest of the plant. 
The lack of any significant effect of treatments on $R_{\mathrm{d}}$ indicates that lower photosynthesis rates were not influenced by higher substrate consumption (Table 3). Similar results were observed in mango leaves by Urban et al. (2004). The finding that pruning treatment did not affect light-response curves at PPFD below $700 \mu \mathrm{mol} \mathrm{m} \mathrm{m}^{-2} \mathrm{~s}^{-1}$ (Figure 4) and $a_{\text {light }}$ (Table 3), indicates that the utilization of excitation energy is matched by a similar carbon metabolism rate when moderate to low light intensities are experienced. Although light flux density through the plant canopy was not measured in this study, our leaf area results suggest that an important number of leaves experienced moderate to low irradiances, hence, their photosynthesis could be potentially limited by light rather than by fruit assimilate demand. Given that changes in $a_{\text {light }}$ have been also associated with proportional changes in $F v / F m$ related to photo-inhibition of PSII (Duan et al., 2008), lower photosynthesis rates found in conventionally and severely pruned plants were apparently not related with this phenomenon.

Depressed $A^{\text {sat }}$ has been also related with: i) decreasing $g_{\mathrm{s}}$ associated changes in $C_{\mathrm{i}}$, ii) accumulation of soluble sugars in leaves associated to a decrease in electron transport rate, iii) lower nitrogen content in leaves, iv) alterations in any gas exchange component such as an increase in $R_{\mathrm{d}}$ (Urban et al., 2004). We found that measured $A^{\text {sat }}$ and $g_{\mathrm{s}}$ were tightly correlated through a curvilinear relationship (Figure 5A), which reflects a proportionally larger increase in $g_{\mathrm{s}}$ than in $A^{\text {sat }}$ with increasing fruit load. On the other hand, this response suggests that the coregulation of photosynthesis and transpiration was not affected by pruning treatments. Similar results were found for coffee trees by DaMatta et al., (2008) and Franck et al., (2006). Decreased $g_{\mathrm{s}}$ resulted in lower $C_{\mathrm{i}}$ in leaves, indicating that a limiting $\mathrm{CO}_{2}$ concentration in the stomata could be associated with the loss of $\mathrm{CO}_{2}$ fixation capacity when fruit load steadily decreased as result of a decreasing pruning intensity (Figure 5B). According to Li et al. (2007), Nebauer et al. (2011), and Urban et al. (2004), decreased $A^{\text {sat }}$ was not attributable to a $g_{\mathrm{s}}$-associated decrease in $C_{\mathrm{i}}$, when photosynthesis was down-regulated by end-products. Although, end-products of photosynthesis were not measured in this study, from our results we can speculate that endproduct of photosynthesis were possibly not accumulated in 'Brigitta' blueberry leaves as a significant and positive correlation between $g_{\mathrm{s}}$ and $C_{\mathrm{i}}$ occurred. Accordingly, DaMatta et al. (2008), proposed that decreased $A^{\text {sat }}$ in defruited coffee trees was independent of carbon metabolism and directly related to lower $\mathrm{CO}_{2}$ availability coupled with lower $g_{\mathrm{s}}$.

\section{Conclusion}

This study provides new evidence of the effect of pruning severity on leaf and fruit responses in blueberry plants. While slight pruning might provide the potential for higher yield in 4-and 5-year old orchards under southern Chilean conditions, fruit quality would be hampered: lower berry weight, \%DM and sugar content. The variations of these quality attributes were explained by variations in fruit load brought about by pruning treatments. A source-limitation to fruit growth occurred apparently at the initial cell division and initial cell enlargement phases as indicated by decreased fruit RGR. The 
light-saturated photosinthesis was enhanced with decreasing pruning severity, whereas $R_{\mathrm{d}}$ and $a_{\text {light }}$ were unaffected by pruning method. Measured light saturated photosynthesis and $g_{\text {s }}$ were significantly correlated, which suggests that the co-regulation between photosynthesis and transpiration was not affected by pruning treatments. Decreased $g_{\mathrm{s}}$ resulted in lower $C_{\mathrm{i}}$ in leaves, which indicates that a stomatal mediated limitation for $\mathrm{CO}_{2}$ concentration in the mesophyll could be associated with the loss of $\mathrm{CO}_{2}$ fixation capacity when fruit load is decreased by pruning. These outcomes improve our knowledge on the agronomic and physiological factors controlling blueberry yield and fruit quality. An estimation of parameters other than those presently studied, such as those related with carbon metabolism of leaves is the next step to be taken in further pruning studies under field conditions.

\section{Acknowledgements}

The first author thanks "Agrícola Berries San Luís" for facilitating the use and maintenance of the experimental plot, $\mathrm{Mr}$. Aureliano Troncoso for his valuable help in the collection of data, Dr. Francisco Matus for his pertinent suggestions and CONICYT (Chile), FONDEF D06I1100 and Project FRO0601 (Universidad de La Frontera, Chile) for financial support.

\section{References}

Causton, D., Dale, M. 1990. The monomolecular and rectangular hyperbola as empirical models of the response of photosynthetic rate to photon flux density, with applications to three veronica species. Ann Bot. 65, 389394.

DaMatta, F.M., Cunya, R.L., Antunes, W.E., Martins, S.C.V., Araujo, W.L., Fernie, A.R., Moraes, G.A.B.K. 2008. In field-grown coffee trees source-sink manipulation alters photosynthetic rates, independently of carbon metabolism, via alterations in stomatal function. New Phytol. 178, 348357.

Duan, W., Fan, P.G., Wang, L.J., Li, W.D., Yan, S.T., Li, S.H. 2008. Photosynthetic response to low sink demand after fruit removal in relation to photoinhibition and photoprotection in peach trees. Tree Physiol. 28, 123-132.

El-Boray, M.S., Shalam, A.M., Khouri, Z.M. 2013. Effect of different thinning techniques on fruit set, leaf area, yield and fruit quality parameters of prunus persica, L., Batsch cv. Floridaprince. Trends Horticultural Res. 3, $1-13$.

Franck, N., Vaast, P., Génard, M., Dauzat, J. 2006. Soluble sugars mediate sink feedback down-regulation of leaf photosynthesis in field-grown Coffea arabica. Tree Physiol. 26, 517-525.

Gautier, H., Guichard, S., Tchamitchian, M. 2001. Modulation of competition between fruits and leaves by flower pruning and water fogging, and consequences on tomato leaf and fruit growth. Ann Bot. 88, 645-652.

Godoy, C., Monterubbianesi, G., Tognetti, J. 2008. Analysis of highbush blueberry (Vaccinium corymbosum L.) fruit growth with exponential mixed models. Sci. Hortic. $115,368-376$. 
Henton, S., Piller, G.J., Gandar, P.W., 1999. A fruit growth model dependent on both carbon supply and inherent fruit characteristics. Ann. Bot. 83, 509-514.

Léchaudel, M., Joas, J., Caro, Y., Genard, M., Jannoyer, M. 2005. Leaf:fruit ratio and irrigation supply affect seasonal changes in minerals, organic acids and sugars of mango fruit. J. Sci. Food Agric. 8, 251-260.

Li, W.D., Duan, W., Fan, P.G., Yan, S.T., Li, S.H. 2007. Photosynthesis in response to sink-source activity and in relation to end products and activities of metabolic enzymes in peach trees. Tree Physiol. 27, 1307-1318.

Maust, B.,Em., Williamson, J.G., Darnell, R.L. 1999. Effect of flower bud density on vegetative and reproductive development and carbohydrate relations in southern highbush blueberry. J. Amer. Soc. Hort. Sci. $124,532-538$.

Minchin, P.E.H., Snelgar, W.P., Blattmann, P., Hall, A.J. 2010. Competition between fruit and vegetative growth in Hayward kiwifruit. New Zeal. J. Crop. Hort. 38, 101-112.

O’Neal, M. E., Landis, D. A., Isaacs, R. 2002. An inexpensive, accurate method for measuring leaf area and defoliation through digital image analysis. J. Econ. Entomol. 95,1190-1194.

Nebauer, S.G, Renau-Morata, B., Guardiola, J.L., Molina, R.V. 2011. Photosynthesis down-regulation precedes carbohydrate accumulation under sink limitation in Citrus. Tree Physiol. 311, 69-77.
Pavel, E.W., DeJong, T.M. 1993. Source- and sink-limited growth periods of developing fruits indicated by relative growth rate analysis. J. Amer. Soc. Hortic. Sci. 118, 820824.

Quentin, A.G., Close, D.C., Hennen, L.M.H.P., Pinkard, E.A. 2013. Down-regulation of photosynthesis following girdling, but contrasting effects on fruit set and retention, in two sweet cherry cultivars. Plant Physiol. Biochem. 73, 359-367.

Retamales, J.B., Hancock, J.F. 2012. Blueberries. CABI, Wallingford, UK, 336p.

Reyes-Díaz, M., Meriño-Gergichevich, C., Alarcón, E., Alberdi, M., Horst, W.J. 2011. Calcium sulfate ameliorates the effect of aluminum toxicity differentially in genotypes of highbush blueberry (Vaccinium corymbosum L.). J. Soil. Sci. Plant Nutr. 11, 59-78.

Seehuber, C., Damerow, L., Blanke, M. 2011. Regulation of source: sink relationship, fruit set, fruit growth and fruit quality in European plum (Prunus domestica L.) using thinning for crop load management. Plant Growth Regul. 65, 335-341.

Strik, B., Buller, G., Hellman, E. 2003. Pruning severity affects yield, berry weight, and hand harvest efficiency of highbush blueberry. Hortscience. 38, 195-199.

Urban, L., Lechaudel, M., Lu, P. 2004. Effect of fruit load and girdling on leaf photosynthesis in Mangifera indica L. J. Exp. Bot. 44, 2075-2085. 